\title{
Investigation of the relationship between landform classes and electrical conductivity (EC) of water and soil using a fuzzy model in a GIS environment
}

\author{
Marzieh Mokarram ${ }^{1}$ and Dinesh Sathyamoorthy ${ }^{2}$ \\ ${ }^{1}$ Department of Range and Watershed Management, College of Agriculture and Natural Resources of Darab, \\ Shiraz University, Darab, Iran \\ ${ }^{2}$ Science \& Technology Research Institute for Defence (STRIDE), Ministry of Defence, Kajang, Selangor, Malaysia \\ Correspondence to: Marzieh Mokarram (m.mokarram.313@gmail.com)
}

Received: 20 February 2016 - Published in Solid Earth Discuss.: 10 March 2016

Revised: 12 May 2016 - Accepted: 12 May 2016 - Published: 30 May 2016

\begin{abstract}
Soil genesis is highly dependent on landforms as they control the erosional processes and the soil physical and chemical properties. The relationship between landform classification and electrical conductivity (EC) of soil and water in the northern part of Meharloo watershed, Fars province, Iran, was investigated using a combination of a geographical information system (GIS) and a fuzzy model. The results of the fuzzy method for water EC showed $36.6 \%$ of the land to be moderately land suitable for agriculture; high, $31.69 \%$; and very high, $31.65 \%$. In comparison, the results of the fuzzy method for soil EC showed $24.31 \%$ of the land to be as not suitable for agriculture (low class); moderate, $11.78 \%$; high, $25.74 \%$; and very high, $38.16 \%$. In total, the land suitable for agriculture with low EC is located in the north and northeast of the study area. The relationship between landform and EC shows that EC of water is high for the valley classes, while the EC of soil is high in the upland drainage class. In addition, the lowest EC levels for soil and water are in the plains class.
\end{abstract}

\section{Introduction}

The pedogenesis of the soils is determined by the climate (Cerdà, 1998a), the parent material (Prosdocimi et al., 2016) and human management (Debolini et al., 2015; Yan et al., 2015; Zhao et al., 2015; Cerdà et al., 2016), however also as a consequence of the landforms and processes that act on them. Soil features are largely controlled by the landforms on which they are developed. The physiographic penetration on soil properties is recognised based on the progress of the soil-landform relationship (Ali and Moghanm, 2013). The landforms formed by the same geomorphic processes are the main key feature because they can easily be identified, and were responsible for producing the undercoat material of the soils (Park and Burt, 2002; Henderson et al., 2005; Mini et al., 2007; Poelking et al., 2015). Previous studies have shown that there is a clear relationship between landform and soils, in that landforms and soil both control hydrological erosional, biological and geochemical cycles. Based on the type of landform, other parameters of watersheds can be predicted, such as soil, erosion, biological parameters and so on (Berendse et al., 2015; Brevik et al., 2015; Decock et al., 2015; Keesstra et al., 2012; Adugna et al., 2015; OchoaCueva et al., 2015; Smith et al., 2015).

A geographical information system (GIS), with features such as the ability to acquire and exchange many different sources, organisation, retrieval and display of data, analysis of numerous data and possibility to provide multiple services, has been introduced as an efficient tool in planning. Combining a GIS with fuzzy logic provides a comparatively new land evaluation method (Badenko and Kurtener, 2004; Oinam et al., 2014; Wang et al., 2015). Incorporating both of these methods is more flexible, and reflects human creativeness and understanding in making decisions. Fuzzy inference is considered as a deduction for mathematical modelling in imprecise and vague processes, i.e. uncer- 
tainty about data, and thus creates a context for modelling uncertainty (Kurtener, 2005).

Ali and Moghanm (2013) studied the variation of soil properties over the landforms around Idku Lake, Egypt, with the spatial distribution of $\mathrm{CaCO}_{3}$, electrical conductivity $(\mathrm{EC})$, organic matter $(\mathrm{OM}), \mathrm{pH}$, nitrogen $(\mathrm{N})$, phosphorus $(\mathrm{P})$, potassium $(\mathrm{K})$, iron $(\mathrm{Fe})$, manganese $(\mathrm{Mn})$, copper $(\mathrm{Cu})$ and zinc $(\mathrm{Zn})$ over the various landforms discussed in detail. The results showed that the changes of $\mathrm{CaCO}_{3}, \mathrm{EC}$ and $\mathrm{OM}$ are minimal in the landforms of sand sheets, hammocks, sabkhas, clay flats and former lake bed.

Aliabadi and Soltanifard (2014) apply a GIS and fuzzy inference for determination of the impact of water and soil EC and calcium carbonate on wheat crops. Regarding the results of the fuzzy inference system, $76 \%$ accuracy was achieved using the Mamdani's method and $52 \%$ of accuracy was achieved for the Sugeno technique.

In addition, El-Keblawy et al. (2015) investigated relationships between landforms, soil characteristics and dominant xerophytes in the northern United Arab Emirates. Soil texture, electrical conductivity (EC) and $\mathrm{pH}$ were determined in each sample point. The results showed that soil and landforms also control the geomorphological and hydrological processes (Cerdà and García-Fayos, 1997; Cerdà, 1998b; Dai et al., 2015; Nadal-Romero et al., 2015).

One of the largest wheat-producing regions in Iran is located in the Shiraz Plain, Fars province (Bijanzadeh et al., 2014). The aim of this study is to investigate the relationship between landform classes and EC of water and soil in this area using a combination of a GIS and a fuzzy model. The methodology employed in this study is summarised in Fig. 1.

\section{Material and methods}

The study area has an area of $3909 \mathrm{~km}^{2}$ and is located at a longitude of $29^{\circ} 06-29^{\circ} 43 \mathrm{~N}$ and a latitude of $52^{\circ} 18$ to $53^{\circ} 28 \mathrm{E}$ (Fig. 2). The altitude of the study area ranges from the lowest at $1433 \mathrm{~m}$ to the highest at $3083 \mathrm{~m}$. The region is located in the north of the Fars province, which has cold winters and hot summers. The average temperature for the area is $16.8^{\circ} \mathrm{C}$, ranging between 4.7 and $29.2^{\circ} \mathrm{C}$ (Soufi, 2004). The research area demonstrates a biodiversity of mountains, relief and lithology, and geological characteristics such as, for instance, sedimentary basin and elevated reliefs (Soufi, 2004). The main agricultural produce consists of grain, fruit and vegetables, while the partly wooded mountains are used for pasture. The main land use types of the region are agriculture, range land, farming and forests.

In terms of geology, the Precambrian Hormoz series and the Quaternary units are the oldest and youngest rocks in the basin, respectively. Spans of outcropped rocks, covering from the Cretaceous to Quaternary, are carbonate sediments of deep to shallow marine facies. These sedimentary

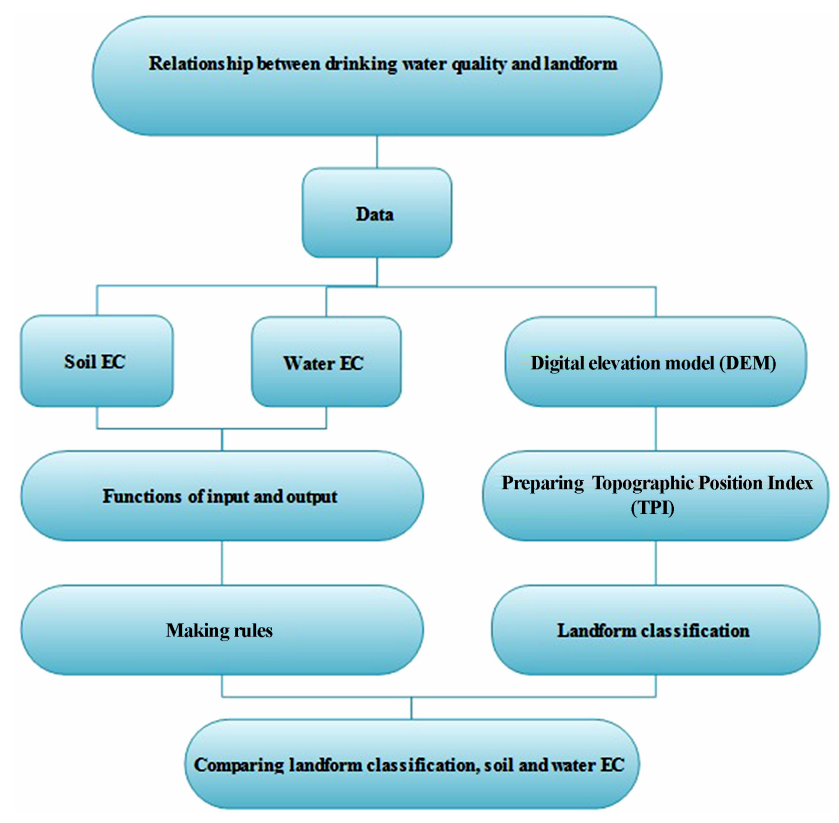

Figure 1. Flowchart of the methodology employed to investigate the relationship between landform classification, and soil and water EC.

sequences include large and small stratigraphic gaps in the form of disconformity and sometimes nonconformity (Khaksar et al., 2006).

The area is situated in an arid and semi-arid region. Rainfall varies from $150 \mathrm{~mm}$ on the plains to $650 \mathrm{~mm}$ on the high mountains, with an average of $350 \mathrm{~mm}$. The rainfall is concentrated in cold seasons, while the precipitation is very low from June to October (Sigaroodi et al., 2014).

During winter, several migratory bird species from north of Caspian Sea, flamingos (Phoenicopterus roseus), common shelducks (Tadorna tadorna) and mallards (Anas platyrhynchos) spend 4 months in the area feeding on brine shrimp (Artemia franciscana). Thus, the lake has important ecological value (Sigaroodi et al., 2014).

\subsection{Inverse distance weighted (IDW) model}

An IDW model was used for interpolating the EC properties. IDW interpolation explicitly implements the assumption that things that are close to one another are more alike than those that are farther apart. To predict a value for any unmeasured location, IDW will be used to measure neighbourhood values in the predicted location. Assumed value of an attribute $f$ at any unsampled point is an average of distance-weighted sampled points lying within a defined neighbourhood around that unsampled point. Basically, it is a weighted moving average 

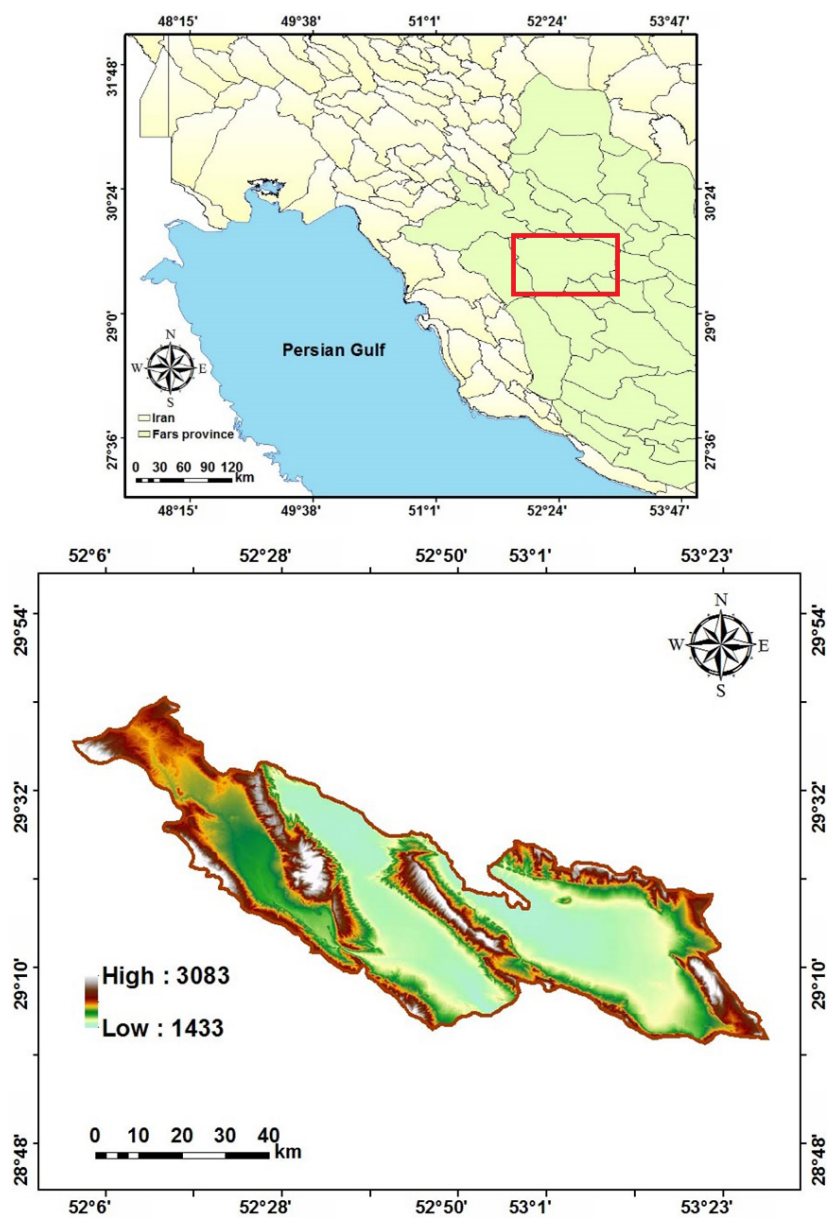

Figure 2. Location of the study area (DEM with spatial resolution of $30 \mathrm{~m}$ ) (source: http://earthexplorer.usgs.gov).

Table 1. Classification of water EC values (Kumar et al., 2003).

\begin{tabular}{ll}
\hline Class & EC $(\mathrm{ds} / \mathrm{m})$ \\
\hline Low & $<0.25$ \\
Moderate & $0.25-0.75$ \\
High & $0.75-2.25$ \\
Very high & $>2.25$ \\
\hline
\end{tabular}

(Burrough et al., 1998):

$\hat{f}\left(x_{0}\right)=\frac{\sum_{i=1}^{n} f\left(x_{i}\right) d_{i j}^{-r}}{\sum_{i=1}^{n} d_{i j}^{-r}}$,

where $x_{0}$ is the estimation point and $x_{i}$ are the data points within a chosen surrounding. The weights $(r)$ are related to distance by $d_{i j}$.

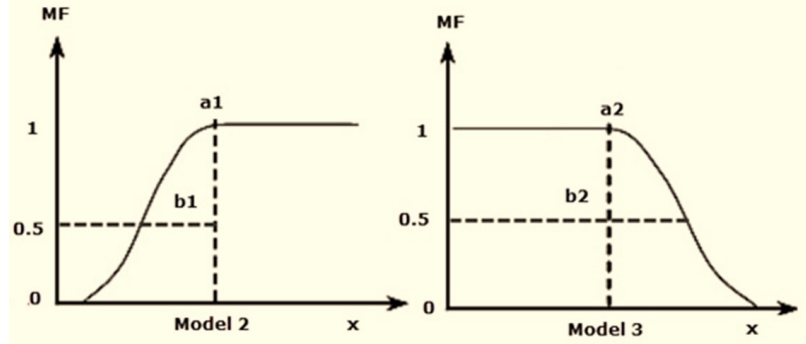

Figure 3. Membership functions.

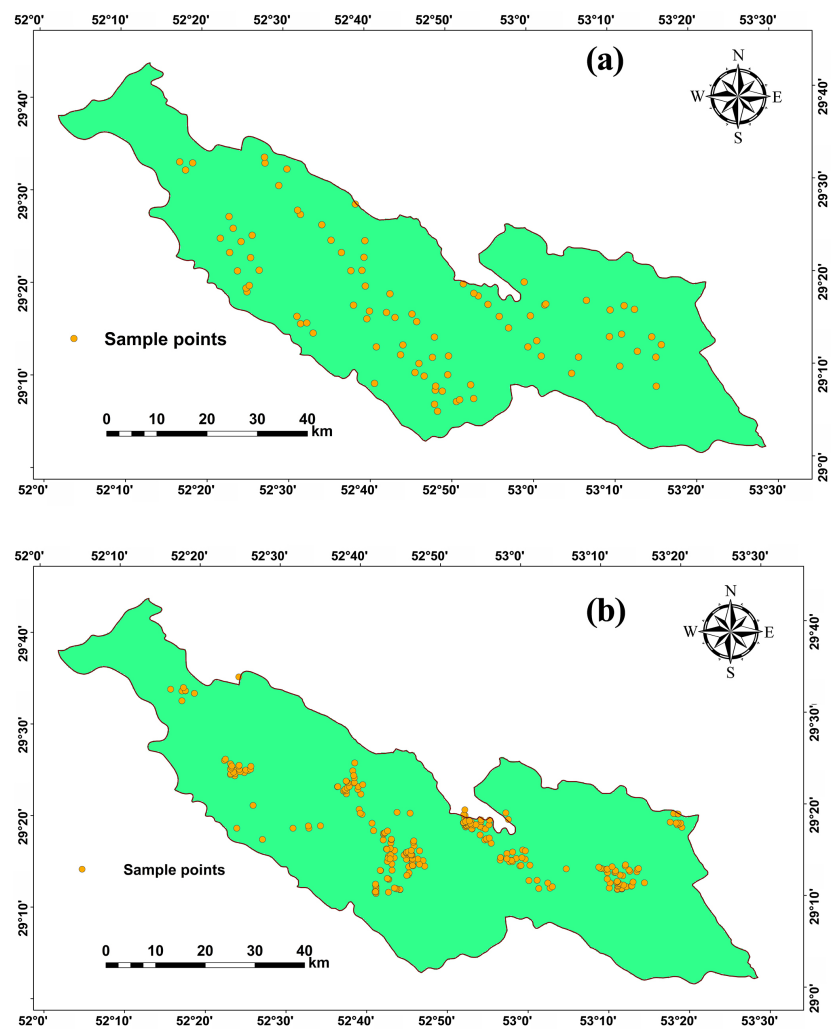

Figure 4. Position of sample points for (a) water and (b) soil EC.

\subsection{Fuzzy method}

In research, model functions are accustomed to computing membership function (MF), as described in Fig. 3 (Burrough and McDonnell, 1998). According to Fig. 3, an asymmetric function needs to be applied (Models 1 and 2) (Fig. 3). If $\operatorname{MF}\left(x_{i}\right)$ shows individual membership value for $i$ th land property $x$, then in the computation process these model functions (Models 1 to 2) show the following form.

For asymmetric left (Model 1),

$\operatorname{MF}\left(x_{i}\right)=\left[1 /\left(1+\left\{\left(x_{i}-a_{i}-b_{1}\right) / b_{1}\right\}^{2}\right)\right]$ if $x_{i}<\left(a_{1}+b_{1}\right)$.

For asymmetric right (Model 2),

$\operatorname{MF}\left(x_{i}\right)=\left[1 /\left(1+\left\{\left(x_{i}-a_{2}+b_{2}\right) / b_{2}\right\}^{2}\right)\right]$ if $x_{i}>\left(a_{2}-b_{2}\right)$. 
Table 2. Classification of soil EC values (Mokarram et al., 2010).

\begin{tabular}{ll}
\hline Class & EC $(\mathrm{ds} / \mathrm{m})$ \\
\hline Low & $<8$ \\
Moderate & $8-12$ \\
High & $12-16$ \\
Very high & $>16$ \\
\hline
\end{tabular}

In this study, in order to define fuzzy-rule-based membership functions, the categories shown in Tables 1 and 2 are used.

\subsection{Landform classification}

The Topographic Position Index (TPI) (Weiss, 2001) compares the elevation of each cell in a digital elevation model (DEM) to the mean elevation of a specified neighbourhood around that cell. Positive TPI (Eq. 4) compares the elevation of each cell in a DEM to the mean elevation of a defined neighbourhood around that cell. Mean elevation is subtracted from the elevation value at the centre (Weiss, 2001):

$\mathrm{TPI}_{i}=Z_{0}-\sum_{n-1} Z_{n} / n$,

where $Z_{0}$ is the elevation of the model point under evaluation, $Z_{n}$ is the elevation of grid and $n$ is the total number of surrounding points employed in the evaluation.

Incorporating TPI at small and large scales permits a number of nested landforms to be distinguished (Table 3). The actual breakpoints among classes can be selected to optimise the classification for a specific landscape. As in slope position classifications, additional topographic metrics, such as, for example, differences of elevation, slope or aspect within the neighbourhoods, can help delineate landforms more accurately (Weiss, 2001).

Additionally, the classes of canyons, deeply incised streams, mid-slope and upland drainages and shallow valleys tend to have strongly negative plane form curvature values. On the other hand, local ridges/hills in valleys, midslope ridges, small hills in plains and mountain tops and high ridges have strongly positive plane form curvature values.

\section{Results and discussion}

\subsection{Inverse distance weighted (IDW) interpolation}

IDW interpolation was used to produce the prediction of soil and water EC, as shown in Fig. 4. According to Fig. 4, sample points were selected randomly in the study area. These data were prepared by the Organization of Agriculture Jahad Fars province in 2012. The lowest and highest output for IDW were 0.016 and 14.48 respectively for water $\mathrm{EC}$, while the lowest and highest soil EC was 0 and 34.5 respectively. The
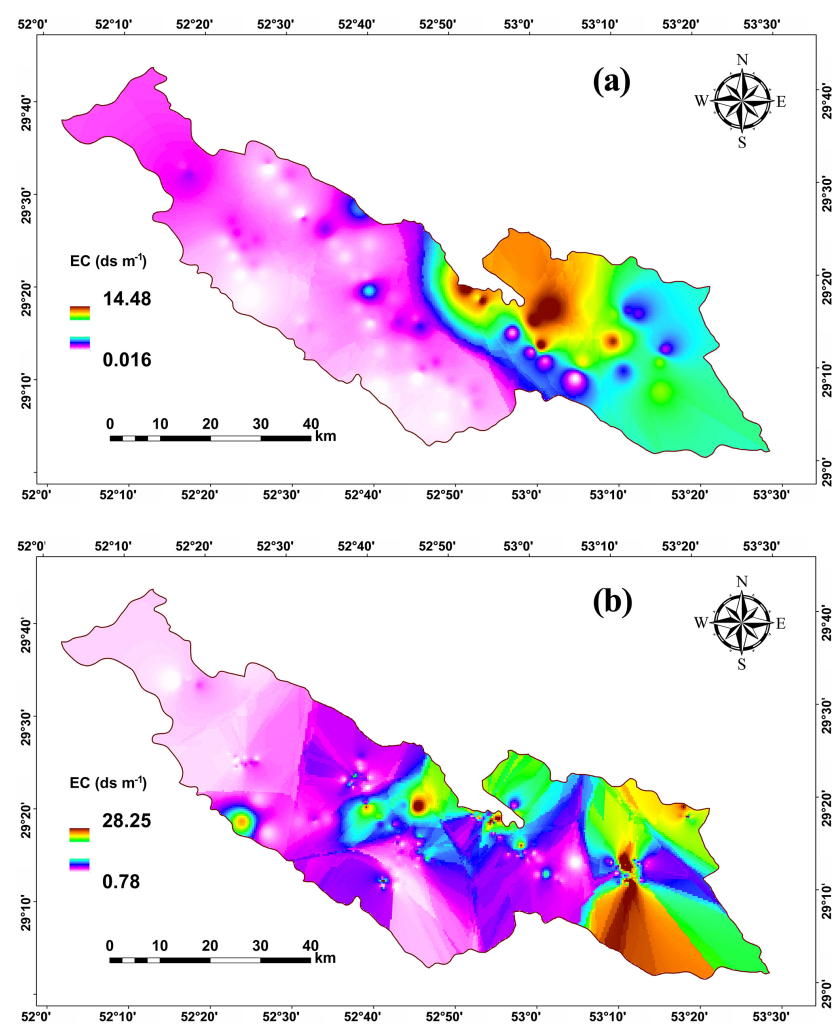

Figure 5. Interpolated maps of study area for (a) water and (b) soil EC.

interpolation maps for soil and water EC are shown in Fig. 5. The statistical properties of the interpolated soil and water EC are shown in Table 4.

\subsection{Fuzzy method}

Fuzzy maps were prepared for soil and water EC, as shown in Fig. 6. The fuzzy values were classified into four classes. $\mathrm{EC}<0.25$, EC between 0.25 and 0.5 , EC between 0.5 and 0.75 and $\mathrm{EC}>0.75$ are in the classes of low, moderate, high and very high respectively (Shobha et al., 2014). The areas of the classes for soil and water EC are shown in Table 5.

For water EC, the fuzzy model showed that $36.6 \%$ of the land was in the moderate class; high, $31.69 \%$; and very high, $31.65 \%$. In comparison, the results of the fuzzy model for soil EC showed that $24.31 \%$ of the land was in the low class; moderate, $11.78 \%$; high, $25.74 \%$; and very high, $38.16 \%$. Based on the results obtained, the land suitable for wheat agriculture is located in the north and northeast in the study area.

\subsection{Landform classification}

In order to determine of relationship between landform classification, and soil and water EC, the landform map of the study area was prepared. Using the TPI, the landform classi- 
Table 3. Topographic Position Index (TPI) thresholds for small and large neighbourhoods used to define landscape feature classes.

\begin{tabular}{lll}
\hline Landform & TPI & \\
& Small neighbourhood & Large neighbourhood \\
\hline Plains & $-1<\mathrm{TPI}<1$ & $-1<\mathrm{TPI}<1^{*}$ \\
Open slopes & $-1<\mathrm{TPI}<1$ & $-1<\mathrm{TPI}<1^{* *}$ \\
U-shaped valleys & $-1<\mathrm{TPI}<1$ & $\mathrm{TPI}<-1$ \\
Mountain tops/high ridges & $\mathrm{TPI}>1$ & $\mathrm{TPI}>1$ \\
Upper slopes/mesas & $-1<\mathrm{TPI}<1$ & $\mathrm{TPI}>1$ \\
Mid-slope drainages/shallow valleys & $\mathrm{TPI}<-1$ & $-1<\mathrm{TPI}<1$ \\
Canyons/deeply incised streams & $\mathrm{TPI}<-1$ & $\mathrm{TPI}<-1$ \\
Mid-slope ridges/small hills in plains & $\mathrm{TPI}>1$ & $-1<\mathrm{TPI}<1$ \\
Upland drainages/headwaters & $\mathrm{TPI}<-1$ & $\mathrm{TPI}>1$ \\
Local ridges/hills in valleys & $\mathrm{TPI}>1$ & $\mathrm{TPI}<-1$ \\
\hline
\end{tabular}

* Plain landform class required a slope of $<0.5$. ** Open slopes landform class required a slope of $>0.5$

Table 4. Descriptive statistics of the water and soil EC.

\begin{tabular}{lrr}
\hline Statistic parameter & $\begin{array}{r}\text { Water EC } \\
(\mathrm{ds} / \mathrm{m})\end{array}$ & $\begin{array}{r}\text { Soil EC } \\
(\mathrm{ds} / \mathrm{m})\end{array}$ \\
\hline Maximum & 14.48 & 28.25 \\
Minimum & 0.016 & 0.78 \\
Average & 3.80 & 3.91 \\
Standard deviation & 6.13 & 3.82 \\
Skewness & 6.54 & 3.09 \\
Kurtosis & 62.97 & 15.46 \\
\hline
\end{tabular}

Table 5. Areas of the classes for water and soil EC.

\begin{tabular}{lrr|rr}
\hline \multirow{2}{*}{ lass } & \multicolumn{2}{c|}{ Area (\%) } & \multicolumn{2}{c}{ Area $\left(\mathrm{km}^{2}\right)$} \\
\cline { 2 - 5 } & Water EC & Soil EC & Water EC & Soil EC \\
\hline Low & 0.00 & 24.31 & 0.11 & 950.23 \\
Moderate & 36.60 & 11.78 & 1430.87 & 460.63 \\
High & 31.69 & 25.74 & 1238.91 & 1006.27 \\
Very high & 31.65 & 38.16 & 1237.10 & 1491.86 \\
\hline
\end{tabular}

fication map of the study area was generated. The TPI maps generated using small and large neighbourhoods are shown in Fig. 7. The TPI is between -106 to 130 and -334 to 533 for 3 and 45 cells for small and large neighbourhoods respectively (Fig. 8). The landform maps generated based on the TPI values are shown in Fig. 8. The classification has 10 classes: high ridges, mid-slope ridges, upland drainage, upper slopes, open slopes, plains, valleys, local ridges, midslope drainage and streams. The areas of the landform classes are shown in Fig. 9. It is observed that the largest landform is streams, while the smallest is plains.

The average EC for each landform class was determined, and the relationship between EC and landform was prepared. According to Fig. 9, the EC of water is high for the valley
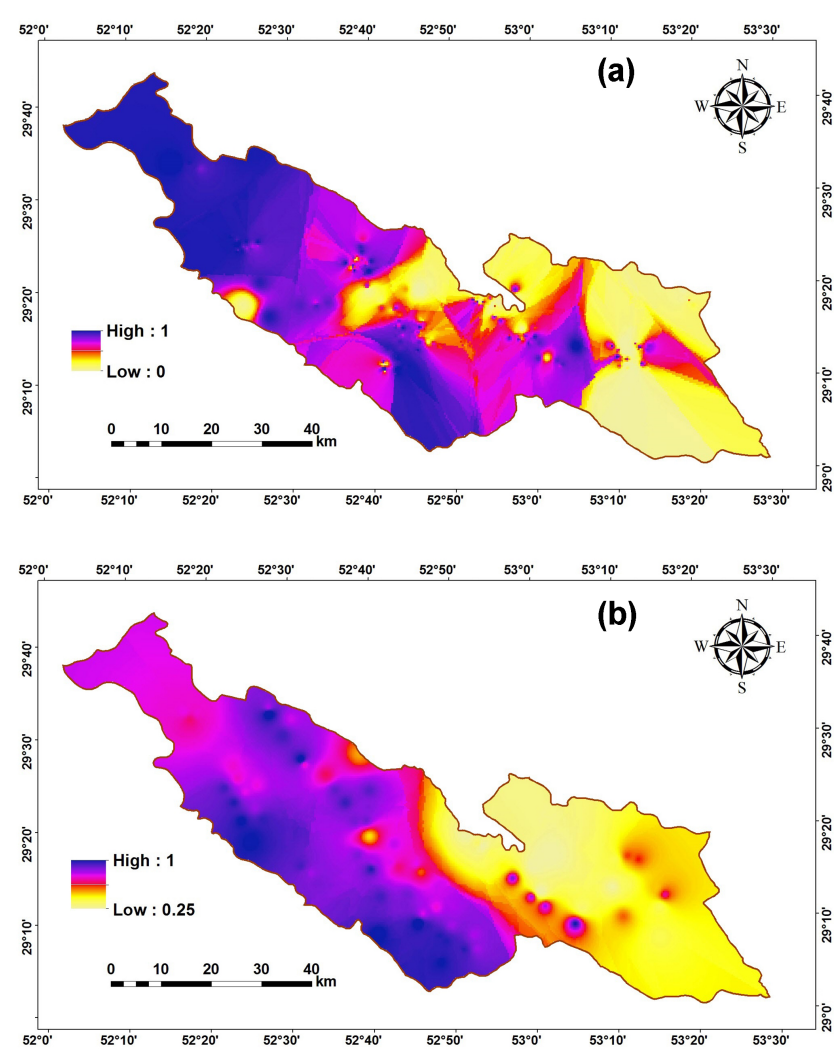

Figure 6. Fuzzy maps of the study area for (a) soil and (b) water EC.

class while the high EC of soil is in the upland drainage class. The lowest EC levels for soil and water are in the plains class.

Dazzi and Monteleone (2001) investigated the relationship between soil properties and landform in Italy. The results show that in plains, the EC value is greater than the other landform types that are similar to results of the study area. Ali and Moghanm (2013), who investigated relationship between soil properties and landform classes in Idku Lake, Egypt, also 

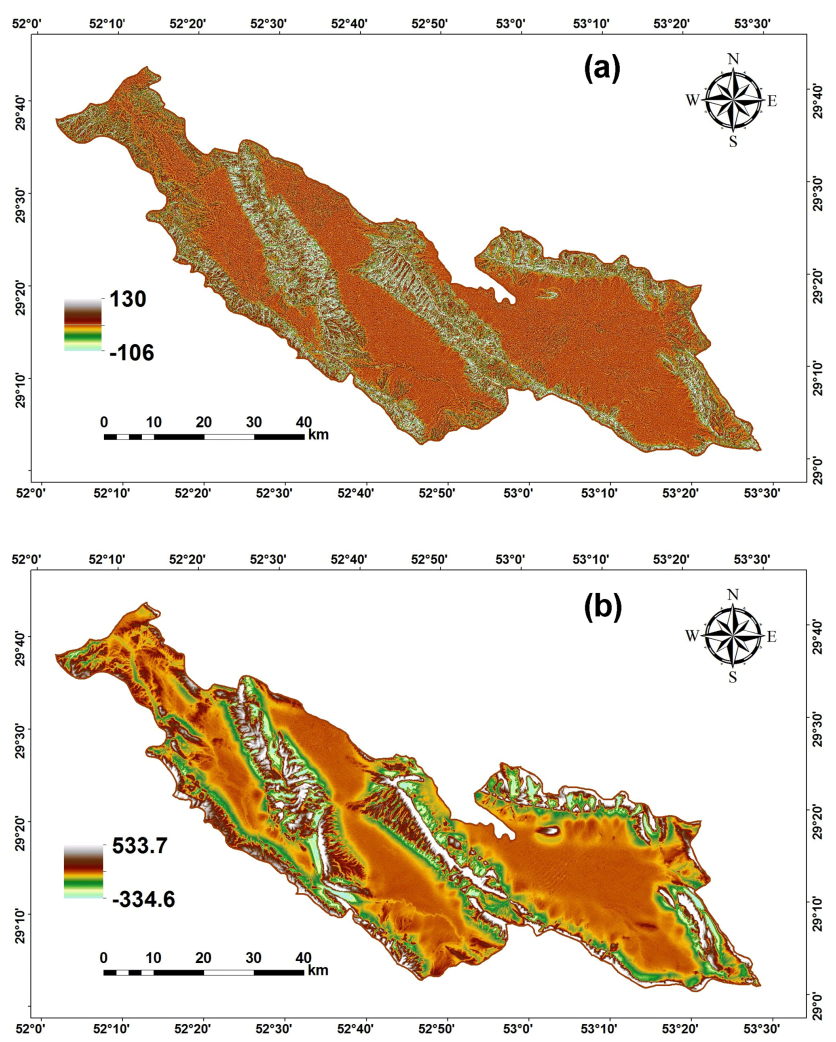

Figure 7. TPI maps generated using (a) small (3 cells) and (b) large (45 cells) neighbourhood.

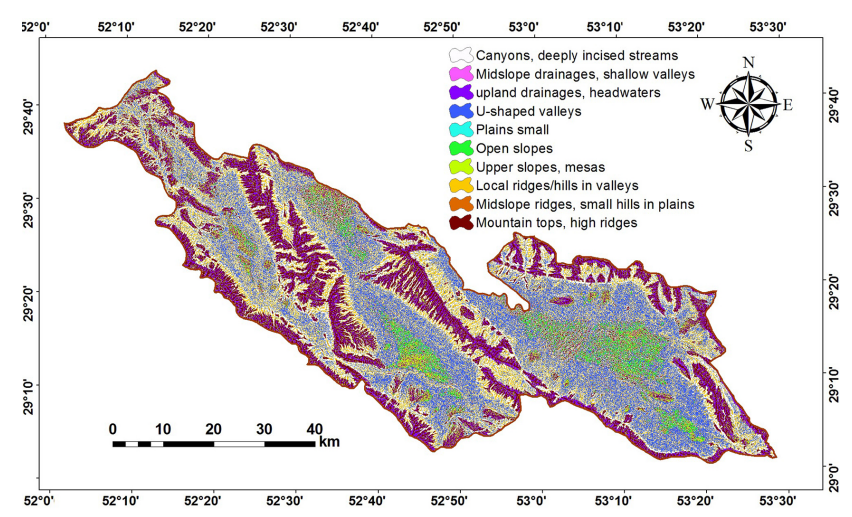

Figure 8. Landform classification using the TPI method.

found that the lowest EC was in plain class. In fact, there is a relationship between soil parameters and land use (Wasak and Drewnik, 2015; Kukal and Bawa Debasish-Saha, 2014). Yu et al. (2014) showed that there is relationship between soil parameters (such as soil organic carbon (SOC), soil total nitrogen (STN)) and types of land cover (grassland, farmland, swampland). Niu et al. (2015) and Yu et al. (2015) investigated the relationship between land use and soil moisture. The results provided an insight into the significance for land use and farming water management in this area. Saha

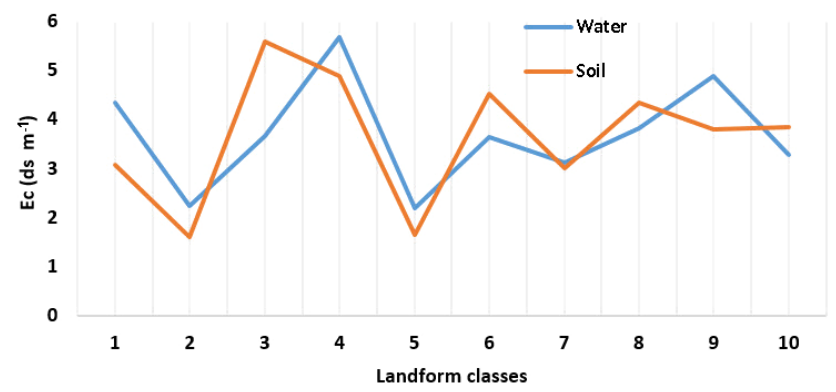

Figure 9. Relationship between landform classes.

and Kukal (2015) found that there is a relationship between soil structural stability and land use. The results indicated the degradation of soil physical attributes due to the conversion of natural ecosystems to farming system and increased erosion hazards. In fact the landforms are located at high elevation such as in mountains; the leaching process is high, while in landforms which are located at low elevation such as plains, the accumulation process is evident. Therefore, in the study area and similar research, the EC value was recorded high in lower topographical positions (Walia and Chamuah, 1994; Singh and Rathore, 2015). In fact EC and other soil properties can be estimated easily and without measuring salinity in the laboratory using satellite data such as from a digital elevation model (DEM) that save time and money.

\section{Conclusion}

In this study, the relationship between classes of landform and electrical conductivity (EC) of soil and water in the Shiraz Plain was investigated using a combination of a geographical information system (GIS) and a fuzzy model. The results of the fuzzy method for water EC showed $36.6 \%$ of the land to be moderately land suitable for agriculture; high, $31.69 \%$; and very high, $31.65 \%$. In comparison, the results of the fuzzy method for soil EC showed $24.31 \%$ of the land to be as not suitable for agriculture (low class); moderate, $11.78 \%$; high, $25.74 \%$; and very high, $38.16 \%$. In total, the land suitable for agriculture with low EC is located in the north and northeast of the study area. The relationship between landform and EC shows that EC of water is high for the valley classes, while EC of soil is high in the upland drainage class. In addition, the lowest EC levels for soil and water are in the plains class.

Acknowledgements. The authors would like to acknowledge the Organization of Agriculture, Jahad Fars, for their assistance during the study and for providing the data set.

Edited by: Edited by: A. Cerdà 


\section{References}

Adugna, A., Abegaz, A., and Cerdà, A.: Soil erosion assessment and control in Northeast Wollega, Ethiopia, Solid Earth Discuss., 7, 3511-3540, doi:10.5194/sed-7-3511-2015, 2015.

Ali, R. R. and Moghanm, F. S: Variation of soil properties over the landforms around Idku lake, Egypt, The Egyptian Journal of Remote Sensing and Space Sciences, 16, 91-101, 2013.

Aliabadi, K. and Soltanifard, H.: The Impact Of Water And Soil Electrical Conductivity And Calcium Carbonate On Wheat Crop Using A Combination Of Fuzzy Inference System And GIS, International Journal of Scientific \& Technology Research, 3, 118124, 2014.

Badenko, V. and Kurtener, D.: Fuzzy modeling in GISenvironment to support sustainable land use planning. The AGILEconference on geographic information science, 29 April-1 May, Heralion, Greece, parallel session a.1, geographic knowledge discovery, 333-342, 2004.

Berendse, F., van Ruijven, J., Jongejans, E., and Keesstra, S.: Loss of plant species diversity reduces soil erosion resistance, Ecosystems, 18, 881-888, doi:10.1007/s10021-015-9869-6, 2015.

Bijanzadeh, E., Mokarram, M., and Naderi, R.: Applying Spatial Geostatistical Analysis Models for Evaluating Variability of Soil Properties in Eastern Shiraz, Iran, Iran Agricultural Research, 33, 35-46, 2014.

Brevik, E. C., Cerdà, A., Mataix-Solera, J., Pereg, L., Quinton, J. N., Six, J., and Van Oost, K.: The interdisciplinary nature of SOIL, SOIL, 1, 117-129, doi:10.5194/soil-1-117-2015, 2015.

Burrough, P. A. and McDonnell, R. A.: Principles of geographical information systems. Spatial Information System and Geostatistics, Oxford University Press, New York, 1998.

Cerdà, A.: Relationships between climate and soil hydrological and erosional characteristics along climatic gradients in Mediterranean limestone areas, Geomorphology, 25, 123-134, doi:10.1016/S0169-555X(98)00033-6, 1998a.

Cerdà, A.: The influence of geomorphological position and vegetation cover on the erosional and hydrological processes on a Mediterranean hillslope, Hydrol. Process., 12, 661-671, 1998b.

Cerdà, A. and García-Fayos, P.: The influence of slope angle on sediment, water and seed losses on badland landscapes, Geomorphology, 18, 77-90, 1997.

Cerdà, A., González-Pelayo, O., Giménez-Morera, A., Jordán, A., Pereira, P., Novara, A., Brevik, E. C., Prosdocimi, M., Mahmoodabadi, M., Keesstra, S., García Orenes, F., and Ritsema, C.: The use of barley straw residues to avoid high erosion and runoff rates on persimmon plantations in Eastern Spain under low frequency - high magnitude simulated rainfall events, Soil Res., 54, 154165, doi:10.1071/SR15092, 2016.

Dai, Q., Liu, Z., Shao, H., and Yang, Z.: Karst bare slope soil erosion and soil quality: a simulation case study, Solid Earth, 6, 985995, doi:10.5194/se-6-985-2015, 2015.

Dazzi, C. and Monteleone, S.: Soils and soil-landform relationships along an Elevational transect in a gypsiferous hilly area in Central Sicily, Italy, Proceedings 7th International meeting of Soils with Mediterranean Type of Climate, Valenzano, Bari, 2001.

Kukal, S. S. and Bawa Debasish-Saha, S. S.: Soil organic carbon stock and fractions in relation to land use and soil depth in the degraded Shiwaliks hills of lower Himalayas, Land Degrad. Dev., 25, 407-416, doi:10.1002/ldr.2151, 2014.
Debolini, M., Schoorl, J. M., Temme, A., Galli, M., and Bonari, E.: Changes in Agricultural Land Use Affecting Future Soil Redistribution Patterns: A Case Study in Southern Tuscany (Italy), Land Degrad. Dev., 26, 574-586, doi:10.1002/ldr.2217, 2015.

Decock, C., Lee, J., Necpalova, M., Pereira, E. I. P., Tendall, D. M., and Six, J.: Mitigating $\mathrm{N}_{2} \mathrm{O}$ emissions from soil: from patching leaks to transformative action, SOIL, 1, 687-694, doi:10.5194/soil-1-687-2015, 2015.

El-Keblawy, A., Abdelfattah, M. A., and Khedr, A.: Relationships between landforms, soil characteristics and dominant xerophytes in the hyper-arid northern United Arab Emirates, J. Arid Environ., 117, 28-36, doi:10.1016/j.jaridenv.2015.02.008, 2015.

Henderson, B. L., Bui, E. N., Moran, C. J., and Simon, D. A. P.: Australia-wide predictions of soil properties using decision trees, Geoderma, 124, 383-398, 2005.

Keesstra, S. D., Geissen, V., van Schaik, L., Mosse, K., and Piiranen, S.: Soil as a filter for groundwater quality, Current Opinions in Environmental Sustainability, 4, 507-516, doi:10.1016/j.cosust.2012.10.007, 2012.

Khaksar, K., Goodarzi, M., Gharibreza, M., and Rahmati, M.: A Study on the Sensivity of Geological Formations to Erosion in the Maharlou Basin, J. Earth Sci., 62, 14 pp., 2006.

Kumar, A., Bohra, C., and Singh, L. K.: Environment, Pollution and Management, APH Publishing, Environmental management, 604 pp., ISBN: 81-7648-419-9, 2003.

Kurtener, D., Green, T. R., Krueger-Shvetsova, E., and Erskine, R. H.: Exploring Relationships Between Geomorphic Factors and Weaht Yield Using Fuzzing Inference System, Hydrology Days, 121-130, 2005.

Mini, V., Patil, P. L., and Dasog, G. S.: A remote sensing approach for establishing the soil physiographic relationship in the Coastal agro eco system of North Karnataka, J. Agric. Sci., 20-23, 524530, 2007.

Mokarram, M., Rangzan, K., Moezzi, A., and Baninemeh, J.: Land suitability evaluation for wheat cultivation by fuzzy theory approache as compared with parametric method. The International Archives of the Photogrammetry, Remote Sensing and Spatial Information Sciences, 38, 140-145, 2010.

Nadal-Romero, E., Revuelto, J., Errea, P., and López-Moreno, J. I.: The application of terrestrial laser scanner and SfM photogrammetry in measuring erosion and deposition processes in two opposite slopes in a humid badlands area (central Spanish Pyrenees), SOIL, 1, 561-573, doi:10.5194/soil-1-561-2015, 2015.

Niu, C. Y., Musa, A., and Liu, Y.: Analysis of soil moisture condition under different land uses in the arid region of Horqin sandy land, northern China, Solid Earth, 6, 1157-1167, doi:10.5194/se6-1157-2015, 2015.

Ochoa-Cueva, P., Fries, A., Montesinos, P., Rodríguez-Díaz, J. A., and Boll, J.: Spatial Estimation of Soil Erosion Risk by Landcover Change in the Andes oF Southern Ecuador, Land Degrad. Dev., 26, 565-573, doi:10.1002/ldr.2219, 2015.

Oinam, B. C., Marx, W., Scholten, T., and Wieprecht, S.: A fuzzy rule base approach for developing a soil protection index map: A case study in the upper awash basin, Ethiopian highlands, Land Degrad. Dev., 25, 483-500, doi:10.1002/ldr.2166, 2014.

Park, S. J. and Burt, T. P.: Identification and characterization of pedo-geomorphological processes on a hillslope, Soil Sci. Soc. Am. J., 66, 1897-1910, 2002. 
Poelking, E. L., Schaefer, C. E. R., Fernandes Filho, E. I., de Andrade, A. M., and Spielmann, A. A.: Soil-landform-plantcommunity relationships of a periglacial landscape on Potter Peninsula, maritime Antarctica, Solid Earth, 6, 583-594, doi:10.5194/se-6-583-2015, 2015.

Prosdocimi, M., Cerdà, A., and Tarolli, P.: Soil water erosion on Mediterranean vineyards: A review, CATENA, 141, 1-21, 2016.

Saha, D. and Kukal, S. S.: Soil structural stability and water retention characteristics under different land uses of degraded lower himalayas of North-West India, Land Degrad. Dev., 26, 263-271, doi:10.1002/ldr.2204, 2015.

Shobha, G., Gubbi, J., Raghavan, K. S., Kaushik, L. K., and Palaniswami, M.: A novel fuzzy rule based system for assessment of ground water potability: A case study in South India, IOSR Journal of Computer Engineering, 15, 35-41, 2014.

Sigaroodi, S. K., Chen, Q., Ebrahimi, S., Nazari, A., and Choobin, B.: Long-term precipitation forecast for drought relief using atmospheric circulation factors: a study on the Maharloo Basin in Iran, Hydrol. Earth Syst. Sci., 18, 1995-2006, doi:10.5194/hess18-1995-2014, 2014.

Singh, D. P. and Rathore, M. S.: Morphological, physical and chemical properties of soils associated in top sequence for establishing taxonomy classes in Pratapgarh District of Rajasthan, India, Afr. J. Agric. Res., 10, 2516-2531, 2015.

Smith, P., Cotrufo, M. F., Rumpel, C., Paustian, K., Kuikman, P. J., Elliott, J. A., McDowell, R., Griffiths, R. I., Asakawa, S., Bustamante, M., House, J. I., Sobocká, J., Harper, R., Pan, G., West, P. C., Gerber, J. S., Clark, J. M., Adhya, T., Scholes, R. J., and Scholes, M. C.: Biogeochemical cycles and biodiversity as key drivers of ecosystem services provided by soils, SOIL, 1, 665685, doi:10.5194/soil-1-665-2015, 2015.
Soufi, M.: Morpho-climatic classification of gullies in fars province, southwest of i.r. iran, International Soil Conservation Organisation Conference - Brisbane, 2004.

Walia, C. S. and Chamuah, G. S.: Soils of riverine plain in Arunachal plain and their suitability for some agricultural crops, J. Indian Soc. Soil Sci., 42, 425-429, 1994.

Wang, J., Ge, A., Hu, Y., Li, C., and Wang, L.: A fuzzy intelligent system for land consolidation - a case study in Shunde, China, Solid Earth, 6, 997-1006, doi:10.5194/se-6-997-2015, 2015.

Wasak, K. and Drewnik, M.: Land use effects on soil organic carbon sequestration in calcareous Leptosols in former pastureland - a case study from the Tatra Mountains (Poland), Solid Earth, 6, 1103-1115, doi:10.5194/se-6-1103-2015, 2015.

Weiss, A.: Topographic Positions and Landforms Analysis (Conference Poster), ESRI International User Conference, San Diego, CA, 9-13, 2001.

Yan, X. and Cai, Y. L.: Multi-Scale Anthropogenic Driving Forces of Karst Rocky Desertification in Southwest China, Land Degrad. Dev., 26, 193-200, doi:10.1002/ldr.2209, 2015.

Yu, B., Stott, P., Di, X. Y., and Yu, H. X.: Assessment of land cover changes and their effect on soil organic carbon and soil total nitrogen in daqing prefecture, China, Land Degrad. Dev., 25, 520 531, doi:10.1002/ldr.2169, 2014.

Yu, Y., Wei, W., Chen, L. D., Jia, F. Y., Yang, L., Zhang, H. D., and Feng, T. J.: Responses of vertical soil moisture to rainfall pulses and land uses in a typical loess hilly area, China, Solid Earth, 6, 595-608, doi:10.5194/se-6-595-2015, 2015.

Zhao, X., Wu, P., Gao, X., and Persaud, N.: Soil Quality Indicators in Relation to Land Use and Topography in a Small Catchment on the Loess Plateau of China, Land Degrad. Dev., 26, 54-61, doi:10.1002/ldr.2199, 2015. 